\title{
Mycosis fungoides preceding lymphomatoid papulosis
}

\author{
Micose fungóide precedendo papulose linfomatóide
}

Larissa Starling de Albuquerque Fernandes ${ }^{1}$, Fernanda Costa Aguiar ${ }^{1}$, Ricardo Barbosa Lima ${ }^{1}$, Omar Lupi², Carlos José Martins ${ }^{2}$

\begin{abstract}
Lymphomatoid papulosis (LyP) is defined as a chronic, recurrent, self-healing papulonecrotic or papulonodular skin disease with histologic features suggestive of a (CD30-positive) malignant lymphoma. In up to $20 \%$ of patients, LyP are preceded by, associated with, or followed by another type of cutaneous or systemic lymphoma, generally mycosis fungoides (MF), primary cutaneous anaplastic large cell lymphoma (C-ALCL). In this case, we describe a case of MF that preceded and continued to coexist with LyP type $C$.
\end{abstract}

Keywords: Lymphomatoid Papulosis. Mycosis Fungoides. Lymphoma, T-Cell, Cutaneous. Cutaneous CD30+ Lymphoproliferative Disorders.

\section{RESUMO}

A papulose linfomatóide (LyP) é definida como uma doença cutânea papulonecrótica ou papulonodular crônica, recorrente, com características histológicas sugestivas de linfoma maligno (CD30-positivo). Em até $20 \%$ dos pacientes, o LyP é precedido por, associado ou seguido por outro tipo de linfoma cutâneo ou sistêmico, geralmente micose fungóide (MF), linfoma cutâneo primário de células grandes anaplásicas (C-ALCL). Neste caso, descrevemos um caso de MF que precedeu e continuou a coexistir com LyP tipo C.

Palavras-chave: Papulose Linfomatoide. Micose Fungoide. Linfoma Cutâneo de Células T. Doenças Linfoproliferativas CD30+.

\section{Introduction}

Cutaneous T-cell lymphomas (CTCL) represent $75-80 \%$ of primary cutaneous lymphomas, with a predominance of mycosis fungoides (MF) and its variants. ${ }^{1,2,3}$ The group of cutaneous CD30+ lymphoproliferative disorders (LPDs) represent the second most common group of CTCL, accounting for approxinately $30 \%$ of cases, that includes Lymphomatoid Papulosis (LyP), primary cutaneous anaplastic large cell lymphoma (pCALCL) and borderline CD30+ lesions. ${ }^{1-4}$
1. Médicos, Dermatologistas, MD. Hospital Universitário Gafrée e Guinle - UNIRIO.

2. Médicos, Dermatologistas, MD, PhD. Hospital Universitário Gafrée e Guinle - UNIRIO.

Conflict of Interest: The authors have no conflict of interest of regarding this paper.
CORRESPONDÊNCIA: Larissa Starling de A. Fernandes Gaffree e Guinle University Hospital - Federal University of State of Rio de Janeiro (UNIRIO)

Recebido em 24/01/2017 Aprovado em 10/05/2017 
Patients with LyP have an increased risk of developing a cutaneous or nodal lymphoid malignancy. In 5 to $20 \%$ of patients, LyP may be preceded or followed by a malignant lymphoma, generally MF, cutaneous or systemic anaplastic large cell lymphoma $(A L C L)$, or Hodgkin lymphoma $(\mathrm{HL}) .{ }^{1-}$ 6

We describe a young patient with MF, who developed regional multiple papules, histologically resembling $\mathrm{Ly} \mathrm{P}$, and undergoing spontaneous regression. The occurrence of both diseases in the same patient and MF preceding LyP is rare.

\section{Case Report}

A female patient, 35 years old, noticed in 2003 pruritic patches on the trunk and limbs. The lesions evolved 2 years later to extensive patches presenting ulceration and spontaneous healing affecting the abdomen. Histopathological examination of the patches, we observe psoriasiform epidermal hyperplasia, small to medium-sized atypical mononuclear cells and epidermotropism (Figure 1A-B). The immunohistochemical panel associated with the morphologic features, was compatible with MF.

The patient noticed injuries on the back of the right hand and left hallux and visited our department in April 2015.

We observed extensive patches in the abdomen. In the hand, papular-necrotic lesion healed spontaneously. On foot, pustule in the hallux, which progressed to ulceration and spontaneous healing (Figure 2A-D). Histopathology from the foot, showed epidermal hyperplasia, dense dermal infiltrate composed of large, atypical lymphoid


Figure 1: A-B: Psoriasiform epidermal hyperplasia, small to medium-sized atypical mononuclear cells and epidermotropism. C-D: Histopathology from the foot, showed epidermal hyperplasia, dense dermal infiltrate composed of large, atypical lymphoid cells. 

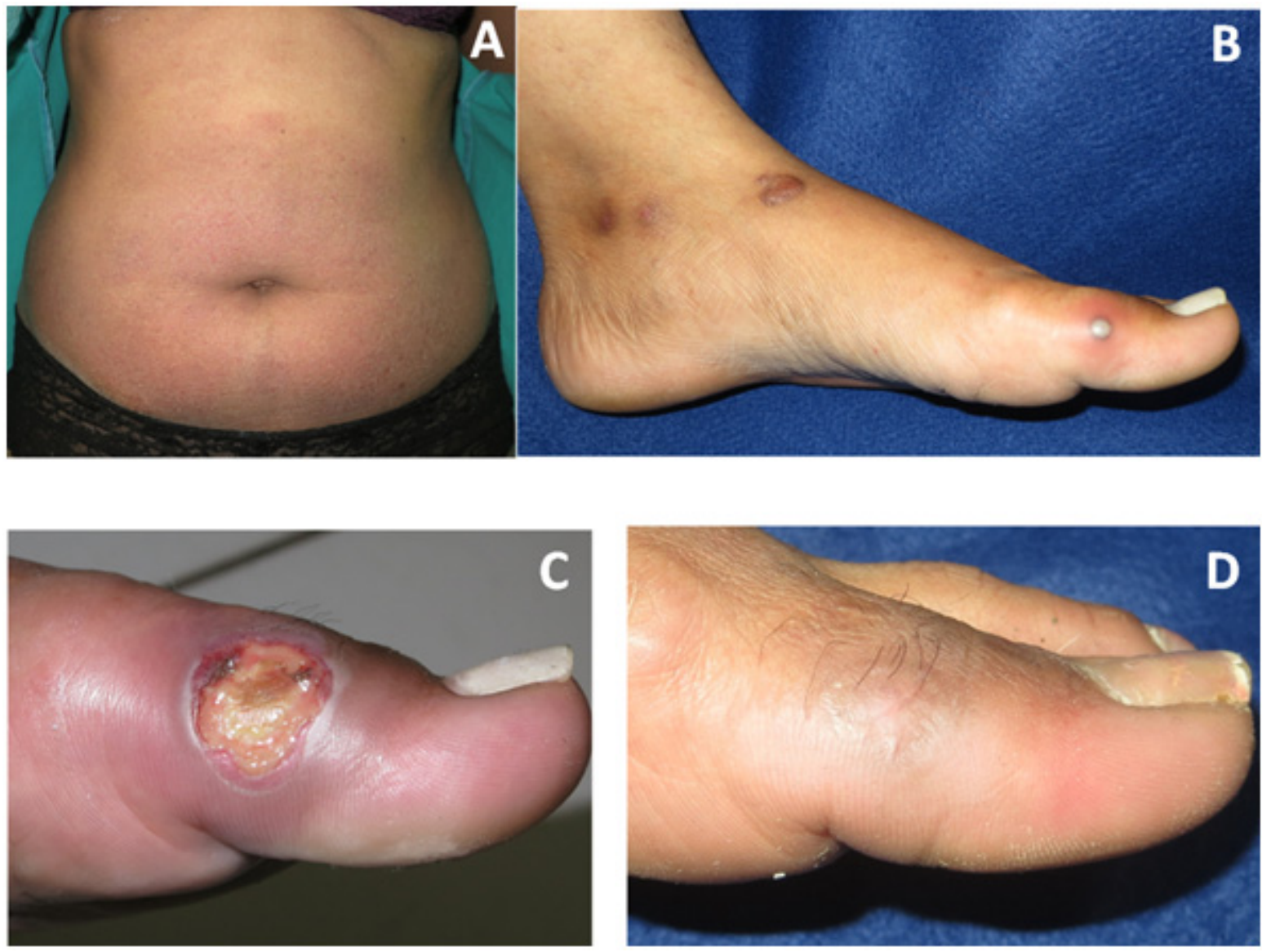

Figure 2: A-D: Extensive patches in the abdomen and on foot, pustule in the hallux, which progressed to ulceration and spontaneous healing

cells(Figure 1C-D). The immunophenotype was CD30-positive. Superficial lymph nodes were not enlarged.

Results of complete blood cells counts, Sezary cells, protein electrophoresis, HIV and HTLV serology, chest X-ray, chest and abdominal computed tomography were either within normal limits or negative.

Based on the biopsy findings and clinical history of spontaneous resolution, a diagnosis of MF preceding LyP. It started Methotrexate $7.5 \mathrm{mg}$ per week and UVB narrowband phototherapy. After a 18-months follow up the patient remained without skin lesions.

\section{Discussion}

The Lyp is a recurrent, selfhealing papulonodular skin eruption(less than $2 \mathrm{~cm}$ ) with histologic features of a CD30+ malignant T cell lymphoma which may progress to ulcerations or areas of central necrosis, mainly in the trunk and thighs. These lesions regress in 3 to 12 weeks. The histologic picture of LyP is extremely variable. Six histologic types have been described. Type C LyP is almost identical to PCALCL, with $>50 \%$ of the infiltrate being large CD30+ atypical cells forming sheets or nodules; it is distinguished from pCALCL only by its smaller size and spontaneous regression with time. ${ }^{1-6}$

Several studies show rate of 10 to $20 \%$ of patients, LyP may be preceded, associated with, or followed by a malignant lymphoma, generally MF, cutaneous ALCL and HD. Most commonly the MF $(40-50 \%)$ is the most frequent association. In a review of 98 cases this association in MF 34\% preceded LyP, as in our patient. ${ }^{1-7}$

This association suggests the possible biological relationship of these two diseases, and 
studies have shown rearrangements monoclonal T cell receptor gene in lymphocytes of both diseases indicating a common origin. ${ }^{7-10}$

In the reported case, the patient referred the onset of erythematous scaly lesions diagnosed as MF, preceding the appearance of papular-necrotic lesions diagnosed as $\mathrm{PL}$, which is not usually described in the literature reviewed. The treatment may hasten lesion healing and reduce the severity the eruption of new crops of lesions. Low dose methotrexate is the most widely used treatments for LyP and UVB therapy has been reported as a safe and effective alternative, with complete response rates of up to $75 \%$ for MF. ${ }^{4-8}$

\section{Conclusion}

The finding of a common clone in the LyP and MF lesions of the same patient strengthens the case for regarding LyP as a form of CTCL. Awareness of the association between LyP and MF by dermatologists and pathologists may lead to improve diagnosis and treatment and may also suggest further speculation as to the relationship between LyP and MF.

\section{References}

1. de la Garza Bravo MM, Patel KP, Loghavi S, Curry JL, Torres Cabala CA, Cason RC, et al. Shared clonality in distinctive lesions of lymphomatoid papulosis and mycosis fungoides occurring in the same patients suggests a common origin. Hum Pathol. 2015;46:558-69.

2. De Souza A, el-Azhary RA, Camilleri MJ, Wada DA, Appert $\mathrm{DL}$, Gibson LE. In search of prognostic indicators for lymphomatoid papulosis: a retrospective study of 123 patients. J Am Acad Dermatol. 2012;66:928-37.

3. Queller JN, Bognet RA, Kozic H, Lee JB, Sahu J, Hyde PM. A case of mycosis fungoides and lymphomatoid papulosis occurring simultaneously in a child. J Clin Aesthet Dermatol 2012;5:46-8.

4. Magorien J, Hillman JD, Pinter-Brown LC, Said J, Chiu MW. Acral lymphomatoid papulosis associated with poikilodermatous mycosis fungoides. Dermatol Online J. 2013;19:1.

5. De Souza A, Carter JB, Harris NL, Ferry JA \& Duncan LM. Contribution of longitudinal follow up and clinical pathological correlation in the diagnosis CD30-positive skin infiltrates. J Cutan Pathol. 2015; 42: 452-8.
6. Fauconneau A, Pham-Ledard A, Cappellen D, Frison E, Prochazkova-Carlotti M, Parrens M, et al. Assessment of diagnostic criteria between primary cutaneous anaplastic large-cell lymphoma and CD30-rich transformed mycosis fungoides; a study of 66 cases. Br J Dermatol. 2015; 172:1547-54.

7. Zackheim HS, Jones C, LeBoit PE, Kashani-Sabet M, McCalmont TH, Zehnder J. Lymphomatoid papulosis associated with mycosis fungoides: a study of 21 patients including analyses for clonality. J Am Acad Dermatol. 2003;49:620-3.

8. Kunishige $\mathrm{JH}$, McDonald $\mathrm{H}$, Alvarez $\mathrm{G}$, Johnson M, Prieto V, Duvic M. Lymphomatoid papulosis and associated lymphomas: a retrospective case series of 84 patients. Clin Exp Dermatol. 2009;34:576-81.

9. Calzado-Villarreal L, Polo-Rodriguez I, Ortiz-Romero PL. Sindrome linfoproliferativo CD30+ cutáneo primario. Actas dermo-sifiliogr. 2010;101:119-28.

10. Nakahigashi K, Ishida Y, Matsumura Y, Kore-Eda S, Ohmori $\mathrm{K}$, Fujimoto $\mathrm{M}$, et al. Large cell transformation mimicking regional lymphomatoid papulosis in a patient with mycosis fungoides. J Dermatol. 2008;35: 283-8. 